University of Nebraska - Lincoln

DigitalCommons@University of Nebraska - Lincoln

August 2004

\title{
Genetic correlation of ram sexual performance with ewe reproductive traits of four sheep breeds
}

G. Snowder

USDA, ARS, US Meat Animal Research Center

J. N. Stellflug

USDA, ARS, US Sheep Experiment Station

L. Dale Van Vleck

University of Nebraska-Lincoln, dvan-vleck1@unl.edu

Follow this and additional works at: https://digitalcommons.unl.edu/usdaarsfacpub

Part of the Agricultural Science Commons

Snowder, G.; Stellflug, J. N.; and Van Vleck, L. Dale, "Genetic correlation of ram sexual performance with ewe reproductive traits of four sheep breeds" (2004). Publications from USDA-ARS / UNL Faculty. 191. https://digitalcommons.unl.edu/usdaarsfacpub/191

This Article is brought to you for free and open access by the U.S. Department of Agriculture: Agricultural Research Service, Lincoln, Nebraska at DigitalCommons@University of Nebraska - Lincoln. It has been accepted for inclusion in Publications from USDA-ARS / UNL Faculty by an authorized administrator of DigitalCommons@University of Nebraska - Lincoln. 


\title{
Genetic correlation of ram sexual performance with ewe reproductive traits of four sheep breeds
}

\author{
G.D. Snowder ${ }^{\mathrm{a}, *}$, J.N. Stellflug ${ }^{\mathrm{b}}$, L.D. Van Vleck ${ }^{\mathrm{c}}$ \\ a USDA, ARS, US Meat Animal Research Center, P.O. Box 166, Clay Center, NE 98633, USA \\ ${ }^{\mathrm{b}}$ USDA, ARS, US Sheep Experiment Station, HC 62, Box 2010, Dubois, ID 83423, USA \\ ' USDA, ARS, MARC, Department of Animal Science, University of Nebraska, \\ Lincoln, NE 68583, USA
}

Received 3 November 2003; received in revised form 17 January 2004; accepted 13 April 2004

\begin{abstract}
Rams express differences in sexual performance during the breeding season. Breeding rams with high sexual performance scores as measured during a sexual performance test can improve flock fertility. Whether selecting rams for high sexual performance score will indirectly improve ewe reproductive performance is not known. The objective of this study was to estimate the genetic correlation between sexual performance scores of rams and reproduction of ewes. Sexual performance scores of rams and reproductive performance (number of lambs born per ewe exposed and number of lambs weaned per ewe exposed) from four breeds were analyzed with univariate and bivariate animal models using REML. A total of 4685 records for sexual performance scores of rams were obtained from the US Sheep Experiment Station (Columbia, $n=807$; Polypay, $n=1668$; Rambouillet, $n=1208$; and Targhee, $n=1002$ ). Reproductive performance of ewes was based on 35,154 records (Columbia, $n$ $=7693$; Polypay, $n=9229$; Rambouillet, $n=10,954$; and Targhee, $n=7278$ ). Estimates of heritability for sexual performance score of rams were larger for the Columbia $(0.31 \pm 0.09)$ and Polypay $(0.30 \pm 0.08)$ than that for Rambouillet $(0.14 \pm 0.07)$ and Targhee breeds $(0.17 \pm 0.08)$. Overall breed heritability estimate was $0.22 \pm 0.04$. Heritability estimates for number of lambs born were larger $(0.05-0.11)$ than for number of lambs weaned (0.02-0.05). Estimates of genetic correlation between sexual performance score and number of lambs born were near zero ( -0.09 to 0.02$)$ except for the Columbia breed $(0.24 \pm 0.20)$. Estimates of genetic correlation between sexual performance score of the ram and number of lambs weaned varied by breed (Columbia, $0.28 \pm 0.26$; Polypay, $0.00 \pm 0.25$; Rambouillet, $-0.17 \pm 0.25$; and Targhee, $0.32 \pm 0.28$ ). Overall breed genetic correlations of sexual performance of rams with number of lambs born and weaned were $0.00 \pm 0.10$ and $0.00 \pm 0.12$, respectively. Because of the low heritability of ewe reproductive traits and their apparently nil to low genetic correlation with sexual performance scores of rams, selection and use of rams with high
\end{abstract}

\footnotetext{
* Corresponding author. Tel.: +1 402762 4167; fax: +1 4027624173.

E-mail address: snowder@email.marc.usda.gov (G.D. Snowder).
} 
sexual performance scores would not be expected to result in much indirect response for improved reproduction of ewes.

(C) 2004 Elsevier B.V. All rights reserved.

Keywords: Behavior; Fertility; Heritability; Libido; Prolificacy

\section{Introduction}

Differences in sexual behavior among rams have been recognized for many years (Terrill, 1937). Procedures to rank rams for breeding soundness based on their sexual behavior were consequently developed (Wiggins et al., 1953; Kilgour and Whale, 1980; Perkins and Fitzgerald, 1992). Tests for ranking rams on sexual performance are highly repeatable (Snowder et al., 2002) and reliable predictors of sexual performance under field conditions (Ibarra et al., 2000). Rams with high scores for sexual behavior can improve flock fertility during breeding (Mattner et al., 1971; Perkins et al., 1992). Ram sexual performance is genetically influenced (Kilgour, 1985; Purvis, 1985; Snowder et al., 2002). Whether selection and breeding of rams with high sexual performance scores will indirectly improve the genetics of ewe reproduction is not clearly known.

Favorable genetic relationships among male sexual phenotypes and female reproductive traits have been previously described. Scrotal size has been correlated with ovulation rate, litter size, and age at puberty in several species (sheep, Hanrahan and Quirke, 1988; swine, Proud et al., 1976; mice, Islam et al., 1976). After 22 generations of selection for increased litter size in mice, a realized genetic correlation between testis weight and litter size of 0.42 was reported (Eisen and Johnson, 1981). Some studies observed small or no relationship among male and female reproductive traits. Selection for increased boar testis weight at 120 days of age did not increase gilt ovulation rate (Johnson et al., 1994). In sheep, ovulation rate of daughters from rams with high sexual performance scores did not differ from that of daughters from rams with low sexual performance scores (Bench et al., 2001).

Mating behavior and reproductive success are hormone dependent in both sexes. Serum testosterone level has a high correlation $(r=0.90)$ with sexual performance of rams during mating (Sanford et al., 1977). A peak in estradiol is associated with behavioral estrus in the ewe (Norman et al., 1968; Plotka and Erb, 1969). Because sex hormones such as testosterone and estradiol are modulated by the hypothalamo-pituitary axis a genetic link between male sexual behavior and female reproductive performance may be measurable. The objective of the current study was to determine if sexual performance of rams and reproduction of ewes are genetically associated.

\section{Animals, materials and methods}

From 1990 to 2000, rams at the US Sheep Experiment Station, Dubois, ID were tested and scored for sexual performance prior to breeding or being sold at public auction. Records for sexual performance scores from rams representing four breeds (Columbia, $n=807$; Polypay, $n=1668$; Rambouillet, $n=1208$; and Targhee, $n=1002$; Table 1 ) were analyzed. 
Table 1

Number of records and means for ram libido score and ewe reproductive traits by breed

\begin{tabular}{|c|c|c|c|c|c|c|}
\hline \multirow[t]{2}{*}{ Trait } & \multicolumn{2}{|c|}{ Ram libido score } & \multicolumn{2}{|c|}{ Number of lambs born } & \multicolumn{2}{|c|}{ Number of lambs weaned } \\
\hline & Records & Mean & Records & Mean & Records & Mean \\
\hline Columbia & 807 & $3.3 \pm 0.05$ & 7693 & $1.4 \pm 0.01$ & 7611 & $1.0 \pm 0.01$ \\
\hline Polypay & 1668 & $3.6 \pm 0.04$ & 9229 & $1.8 \pm 0.02$ & 9106 & $1.2 \pm 0.01$ \\
\hline Rambouillet & 1208 & $3.6 \pm 0.04$ & 10,954 & $1.5 \pm 0.01$ & 10,523 & $1.1 \pm 0.01$ \\
\hline
\end{tabular}

All research protocols were reviewed and approved by the location animal care and safety committee. In early August, sexually naive yearling rams and older rams (2-4 years of age) previously exposed to ewes were scored for sexual performance. The scoring for sexual performance was conducted by exposing individual rams to three induced-estrual ewes for $30 \mathrm{~min}$ (Perkins and Fitzgerald, 1992). Testing pens were outside, were $17.5 \mathrm{~m} \times 13.1 \mathrm{~m}$ in size, and had solid wooden walls which were $4.4 \mathrm{~m}$ high. No feed or water was available in the pens. The ram and ewes roamed freely in the testing pen. Observers recording the data were seated outside the pen. Numbers of mounts and ejaculations were recorded and used to categorize the sexual performance of the ram (Perkins, 1991). Scores ranged from 1 to 6 with scores increasing from sexually inactive to highly sexually active in the presence of estrual ewes. Overall average sexual performance score was $3.5 \pm 1.54$.

Reproductive performance of ewes was evaluated from lambing records for the same four breeds (Columbia, $n=7693$; Polypay, $n=9229$; Rambouillet, $n=10,954$; and Targhee, $n=7278$; Table 1). Prolificacy traits included total number of lambs born per ewe exposed and number of lambs weaned per ewe exposed. Ewes, in groups of 10-20, were exposed to a single ram for at least one breeding cycle (approximately 21 days) in late October. Management of ewes and lambs from breeding to weaning was previously described (Bromley et al., 2001). Average weaning age was 112 days. Numbers of records and means for the traits are presented by breed in Table 1 . Because the objective was to estimate the genetic correlation between sexual performance scores of rams and reproductive traits of ewes within each breed, breed differences were not estimated. Breed differences for reproductive traits have been described by Bromley et al. (2000).

Genetic parameters from both univariate and bivariate analyses for all traits were estimated with animal models separately for each breed and overall breeds. The model for sexual performance score of rams included fixed effects of selection line and year of record. A permanent environmental effect of the ram was included to account for repeated measures. Age and weight of the ram at time of the sexual performance test were used as linear covariates. Models for number of lambs born and number of lambs weaned included fixed effects of selection line, year of record, and age of ewe. A permanent environmental effect of the ewe was included to account for the repeated measures of lambing and weaning traits. Models for overall breeds included breed as a fixed effect.

Estimates of variance components were obtained by a derivative-free algorithm for REML (Graser et al., 1987) with the computer programs of Boldman et al. (1995). Convergence was considered to have been reached when the variance of the $-2 \log$ likelihoods in the simplex was less than $1 \times 10^{-6}$. After initial convergence, four restarts were performed 
to ensure global convergence as determined when $-2 \log$ likelihood did not change to the second decimal. The standard errors of the heritability estimates were based on the average information matrix and the 'delta' method for the univariate models (e.g., Dodenhoff et al., 1998). The standard errors of the genetic correlations were also computed by the 'delta' method by reparameterizing the bivariate models to equivalent univariate models according to Nephawe et al. (2003).

A genetic correlation between sexual performance of rams and ewe reproductive traits was obtained using a two trait model. All rams and all ewes were considered in the analyses. A ram would have a sexual performance score but missing values for ewe reproductive traits and a ewe would have a missing value for a sexual performance score. Because the traits were measured on different sexes, correlations would not exist within the uncorrelated, permanent environmental effects and residual effects for the pair of traits. Therefore, these covariances were held constant at zero. Estimation of genetic correlations between sexual performance of rams and ewe reproductive traits was accomplished by considering the genetic relationships between ram and ewes, and all animals in the data set.

\section{Results}

Estimates of variance components with the univariate model for sexual performance score of rams for all four breeds are reported in Table 2. The phenotypic variance was largest in the Polypay breed. Estimates of direct heritability for ram sexual performance varied among breeds. Heritability estimates were larger for Columbia and Polypay breeds ( 0.31 and 0.30 , respectively) compared to Rambouillet $(0.14)$ and Targhee $(0.17)$. Estimate of the overall heritability is identical to that reported earlier for multiple breeds $(0.22)$ by Snowder et al. (2002).

Heritability estimates for number of lambs born and number of lambs weaned, were low and ranged from 0.02 to 0.11 (Table 3). Heritability estimates for number of lambs born $(0.05-0.11)$ were larger than those for number of lambs weaned $(0.02-0.04)$. These estimates agree with those by Bromley et al. (2000) and Hanford (2001) for number of lambs born and number of lambs weaned. Burfening et al. (1993) reported similar estimates for heritability of number of lambs born and weaned of 0.12 and 0.11 , respectively.

Table 2

Estimates of variance components and genetic parameters ${ }^{\mathrm{a}}$ for ram libido score for four sheep breeds

\begin{tabular}{llllllll}
\hline Breed & $\sigma_{\mathrm{P}}^{2}$ & $\sigma_{\mathrm{A}}^{2}$ & $\sigma_{\mathrm{PE}}^{2}$ & $\sigma_{\mathrm{E}}^{2}$ & $h^{2}$ & $\mathrm{pe}^{2}$ & $e^{2}$ \\
\hline Columbia & 2.41 & 0.74 & 1.07 & 0.60 & $0.31 \pm 0.09$ & $0.44 \pm 0.09$ & $0.25 \pm 0.03$ \\
Polypay & 2.66 & 0.80 & 1.03 & 0.84 & $0.30 \pm 0.08$ & $0.39 \pm 0.08$ & $0.31 \pm 0.03$ \\
Rambouillet & 2.24 & 0.32 & 1.36 & 0.55 & $0.14 \pm 0.07$ & $0.61 \pm 0.07$ & $0.25 \pm 0.03$ \\
Targhee & 2.37 & 0.40 & 1.43 & 0.54 & $0.17 \pm 0.08$ & $0.60 \pm 0.08$ & $0.23 \pm 0.03$ \\
Overall & 2.40 & 0.54 & 1.19 & 0.67 & $0.22 \pm 0.04$ & $0.50 \pm 0.04$ & $0.25 \pm 0.01$ \\
\hline
\end{tabular}

${ }^{\mathrm{a}} \sigma_{\mathrm{P}}^{2}$ : phenotypic variance; $\sigma_{\mathrm{A}}^{2}$ : genetic variance; $\sigma_{\mathrm{PE}}^{2}$ : variance due to permanent environmental effects; $\sigma_{\mathrm{E}}^{2}$ : residual variance; $h^{2}$ : heritability; $\mathrm{pe}^{2}$ : fraction of variance due to permanent environmental effects; $e^{2}:$ fraction of variance due to temporary environmental effects. 
Table 3

Estimates of variance components and genetic parameters ${ }^{\mathrm{a}}$ for ewe reproductive traits for four sheep breeds

\begin{tabular}{|c|c|c|c|c|c|c|c|}
\hline Breed & $\sigma_{\mathrm{P}}^{2}$ & $\sigma_{\mathrm{A}}^{2}$ & $\sigma_{\mathrm{PE}}^{2}$ & $\sigma_{\mathrm{E}}^{2}$ & $h^{2}$ & $\mathrm{pe}^{2}$ & $e^{2}$ \\
\hline \multicolumn{8}{|c|}{ Number of lambs born } \\
\hline Columbia & 0.56 & 0.04 & 0.01 & 0.51 & $0.07 \pm 0.01$ & $0.02 \pm 0.01$ & $0.91 \pm 0.01$ \\
\hline Polypay & 0.69 & 0.06 & 0.03 & 0.60 & $0.08 \pm 0.01$ & $0.04 \pm 0.02$ & $0.88 \pm 0.01$ \\
\hline Rambouillet & 0.48 & 0.05 & 0.02 & 0.41 & $0.11 \pm 0.01$ & $0.04 \pm 0.01$ & $0.85 \pm 0.01$ \\
\hline Targhee & 0.54 & 0.03 & 0.03 & 0.48 & $0.05 \pm 0.01$ & $0.06 \pm 0.02$ & $0.89 \pm 0.01$ \\
\hline Overall & 0.57 & 0.05 & 0.02 & 0.50 & $0.09 \pm 0.00$ & $0.03 \pm 0.01$ & $0.88 \pm 0.00$ \\
\hline \multicolumn{8}{|c|}{ Number of lambs weaned } \\
\hline Columbia & 0.48 & 0.01 & 0.02 & 0.45 & $0.03 \pm 0.01$ & $0.04 \pm 0.01$ & $0.93 \pm 0.01$ \\
\hline Polypay & 0.53 & 0.01 & 0.03 & 0.49 & $0.02 \pm 0.01$ & $0.05 \pm 0.01$ & $0.93 \pm 0.01$ \\
\hline Rambouillet & 0.45 & 0.02 & 0.02 & 0.41 & $0.04 \pm 0.01$ & $0.04 \pm 0.01$ & $0.92 \pm 0.01$ \\
\hline Targhee & 0.48 & 0.02 & 0.01 & 0.45 & $0.04 \pm 0.01$ & $0.01 \pm 0.01$ & $0.95 \pm 0.01$ \\
\hline Overall & 0.48 & 0.02 & 0.01 & 0.45 & $0.04 \pm 0.00$ & $0.03 \pm 0.01$ & $0.93 \pm 0.00$ \\
\hline
\end{tabular}

Estimates of variance components were similar between univariate and bivariate analyses. Therefore, only estimates of heritability and genetic correlations are reported for the bivariate analyses. Estimates of genetic correlations of ram sexual performance score with number of lambs born and with number of lambs weaned varied across breeds (Table 4). The estimate of the genetic correlation between ram sexual performance and number of lambs born was small and positive for the Columbia breed (0.24), but near zero for the other breeds with an average of about 0.06. Standard errors were large in proportion to the genetic correlations, which is common. The estimate of genetic correlation for overall breeds was zero with a small S.E.

Estimates of the genetic correlation between ram sexual performance and number of lambs weaned were small and positive for the Columbia and Targhee breeds $(0.28$ and 0.32 , respectively) and nil for the Polypay breed. However, for the Rambouillet breed the estimate was small and negative $(-0.17)$. Standard errors on these estimates were large. The estimate for overall breeds was zero with a small S.E.

\section{Discussion}

Heritability estimates for sexual performance in rams were higher in Columbia and Polypay breeds. If these are reliable estimates of the parameters, the rate of selection response for sexual performance score of rams in the Columbia and Polypay breed should be about double of that in the Rambouillet and Targhee breeds. Bench et al. (2001) reported that sons of Targhee rams with high scores for sexual performance had a higher frequency of ejaculations compared to sons from rams with low sexual performance scores.

This study identifies a genetic basis for breed differences in ram sexual performance. Prolific breeds have more ram sexual activity when compared to breeds characterized with 
Table 4

Estimates of phenotypic and genetic parameters for ram libido score and ewe reproductive traits from bivariate analyses by breed ${ }^{\mathrm{a}}$

\begin{tabular}{|c|c|c|c|c|c|c|c|c|c|c|}
\hline \multirow{2}{*}{$\begin{array}{l}\text { Trait } \\
\text { parameters }\end{array}$} & \multicolumn{5}{|c|}{ Number of lambs born } & \multicolumn{5}{|c|}{ Number of lambs weaned } \\
\hline & COLU & POLY & RAMB & TARG & Overall & COLU & POLY & RAMB & TARG & Overall \\
\hline$h_{1}^{2}$ & 0.31 & 0.30 & 0.14 & 0.18 & 0.22 & 0.31 & 0.30 & 0.15 & 0.18 & 0.22 \\
\hline$h_{2}^{2}$ & 0.07 & 0.08 & 0.11 & 0.05 & 0.09 & 0.03 & 0.02 & 0.04 & 0.04 & 0.04 \\
\hline$r_{\mathrm{g}}$ & $0.24 \pm 0.20$ & $0.01 \pm 0.17$ & $0.02 \pm 0.19$ & $-0.09 \pm 0.27$ & $0.00 \pm 0.10$ & $0.28 \pm 0.26$ & $0.00 \pm 0.25$ & $-0.17 \pm 0.25$ & $0.32 \pm 0.28$ & $0.00 \pm 0.12$ \\
\hline
\end{tabular}

COLU, Columbia; POLY, Polypay; RAMB, Rambouillet; TARG, Targhee.

${ }^{\mathrm{b}} h_{1}^{2}$, heritability of libido score; $h_{2}^{2}$, heritability of reproductive trait; $r_{\mathrm{g}}$, genetic correlation. 
smaller litter sizes (Tulley and Burfening, 1983; Perkins et al., 1992; Snowder et al., 2002). Sexual performance of pure or crossbred Finnish Landrace rams, such as the Polypay, was greater compared to rams from dual purpose breeds (Tulley and Burfening, 1983; Perkins et al., 1992). Ewe reproductive performance significantly improved when they were exposed to Romanov rams compared to four other ram breeds (Freking et al., 2000).

Ewe reproductive traits have been reported to be of low inheritance, as was estimated in this study. A review of published heritability estimates for reproductive traits in sheep reported weighted mean heritability estimates of 0.12 for litter size at birth and 0.05 for litter size at weaning (Fogarty, 1995). Low heritability estimates for these economically important traits suggest a need to identify other traits that are highly correlated with ewe reproductive performance and have large heritability estimates.

The estimated genetic correlations between sexual performance of rams and number of lambs born were very small, except for the Columbia breed. These small correlations imply that selection to improve ram sexual performance would have a negligible, if any, positive effect on improving ewe reproductive performance in Rambouillet, Targhee, and Polypay breeds. If the correlation for the Columbia breed is really positive, that would be desirable because lambing rate of Columbia ewes is less than that of the other breeds studied. Breeding Columbia rams with high sexual performance scores might be an indirect approach to improving the genetics of lamb production. However, the rate of response to selection should be expected to be very slow because of the low heritability of ewe reproductive traits and its low genetic correlation to sexual performance score of the ram.

The number of lambs weaned might be improved by breeding rams with high sexual performance scores in the Columbia and Targhee breeds because the genetic correlation is in the region of 0.30 . This favorable relationship might be explained by examining the trait of number of lambs weaned which is a composite trait influenced by number of lambs born, maternal ability, and lamb survival. Maternal ability includes maternal behavior to care for and protect lambs to weaning. Sexual performance is also a behavior trait. It is plausible that selection to improve ram mating behavior may indirectly affect ewe maternal behavior.

The negative correlation between sexual performance score of the ram and litter size weaned, if true, in the Rambouillet suggests that although rams with high sexual performance scores may breed more ewes there may be a decrease in the number of lambs weaned. However, the overall breed correlation suggests no correlation between sexual performance of ram and number of lambs weaned. Bench et al. (2001) found no difference in ovulation rate between daughters from rams with high or low sexual performance scores; however, ewe lambs from rams with high sexual performance scores were younger at first behavioral estrus.

\section{Conclusion}

Although selection for ram sexual performance score may enhance flock fertility, the general trend for low genetic correlations between sexual performance of rams with ewe reproductive traits suggests that breeding rams with high sexual performance will have little, if any, positive effect on genetic improvement of number of lambs born or number of lambs weaned. Direct selection on the ewe should be more effective for improving lamb production. 
Because this is the first known reported estimated genetic correlation between male sexual behavior and ewe reproductive performance, future research should confirm these results in other populations and investigate the potential for genetic correlations between male sexual behavior and male performance traits such as growth, feed efficiency, and longevity.

\section{References}

Bench, C.J., Price, E.O., Dally, M.R., Borgwardt, R.E., 2001. Artificial selection of rams for sexual performance and its effect on the sexual behavior and fecundity of male and female progeny. Appl. Anim. Behav. Sci. 72, 41-50.

Boldman, K.G., Kriese, L.A., Van Vleck, L.D., Van Tassell, C.P., Kachman, S.D., 1995. A Manual for Use of MTDFREML. A Set of Programs to Obtain Estimates of Variances and Covariances. US Department of Agriculture, Agricultural Research Service, Clay Center, NE.

Bromley, C.M., Van Vleck, L.D., Snowder, G.D., 2000. Genetic parameters among weight, prolificacy, and wool traits of Columbia, Polypay, Rambouillet, and Targhee sheep. J. Anim. Sci. 78, 846-858.

Bromley, C.M., Van Vleck, L.D., Snowder, G.D., 2001. Genetic correlations for litter weight weaned with growth, prolificacy, and wool traits in Columbia, Polypay, Rambouillet, and Targhee sheep. J. Anim. Sci. 79, 339-346.

Burfening, P.J., Kachman, S.D., Hanford, K.J., Rossi, D., 1993. Selection for reproductive rate in Rambouillet sheep: estimated genetic change in reproductive rate. Small Rumin. Res. 10, 317-330.

Dodenhoff, J., Van Vleck, L.D., Kachman, S.D., Koch, R.M., 1998. Parameter estimates for direct, maternal and grandmaternal genetic effects for birth weight and weaning weight in Hereford cattle. J. Anim. Sci. 76, 2521-2527.

Eisen, E.J., Johnson, B.H., 1981. Correlated responses in male reproductive traits in mice selected for litter size and body weight. Genetics 99, 513-524.

Fogarty, N.M., 1995. Genetic parameters for live weight, fat and muscle measurements, wool production and reproduction in sheep: a review. Anim. Breed. 63, 101-143 (abstract).

Freking, B.A., Leymaster, K.A., Young, L.D., 2000. Evaluation of Dorset, Finnsheep, Romanov, Texel, and Montadale breeds of sheep: I. effects of ram breed on productivity of ewes of two crossbred populations. J. Anim. Sci. 78, 1422-1429.

Graser, H.U., Smith, S.P., Tier, B., 1987. A derivative-free approach for estimating variance components in animal models by restricted maximum likelihood. J. Anim. Sci. 64, 1362-1370.

Hanford, K.J., 2001. Estimates of genetic parameters and genetic change for prolificacy, weight and wool characteristics of Columbia, Targhee and Polypay sheep. Ph.D. Dissertation. University of Nebraska, Lincoln.

Hanrahan, J.P., Quirke, J.F., 1988. Testis size and plasma luteinizing hormone as aids to selection for fecundity in sheep. Anim. Prod. 24, 148 (abstract).

Ibarra, D., Laborde, D., van Lier, E., 2000. Repeatability and relationship with field mating performance of a serving capacity pen test in rams. Small Rumin. Res. 37, 165-169.

Islam, A.B.M., Hill, W.G., Land, R.B., 1976. Ovulation rate of lines of mice selected for testis weight. Genet. Res. $27,23-32$

Johnson, R.K., Eckardt, G.R., Rathje, T.A., Drudik, D.K., 1994. Ten generations of selection for predicted weight of testes in swine: direct response and correlated response in body weight, backfat, age at pubery, and ovulation rate. J. Anim. Sci. 72, 1978-1988.

Kilgour, R.J., 1985. Mating behavior of rams in pens. Aust. J. Exp. Agric. 25, 298-302.

Kilgour, R.J., Whale, R.G., 1980. The relation between mating activity of rams in pens and subsequent flock mating performance. Aust. J. Exp. Agric. Anim. Husb. 20, 5-8.

Mattner, P.E., Braden, A.W.H., George, J.M., 1971. Studies in flock mating of sheep. 4. The relation of libido tests to subsequent service activity of young rams. Aust. J. Exp. Agric. Anim. Husb. 11, 473-477.

Nephawe, K.A., Kachman, S.D., Van Vleck, L.D., 2003. An equivalent single trait animal model to obtain standard errors for estimates of genetic correlations between two traits measured on distinct subsets of animals. J. Anim. Sci. 81 (Suppl. 2), 34 (abstract).

Norman, R.L., Eleftheriou, B.E., Spies, H.G., Hoppe, P., 1968. Free plasma estrogens in the ewe during the estrous cycle. Steroids 11, 667-671. 
Perkins, A., 1991. Physiological indices, sexual behavior, and mating capacity of domestic rams. Ph.D. Dissertation. University of California, Davis.

Perkins, A., Fitzgerald, J.A., 1992. Luteinizing hormone, testosterone, and behavioral response of male-oriented rams to estrous ewes and rams. J. Anim. Sci. 70, 1787-1794.

Perkins, A., Fitzgerald, J.A., Price, E.O., 1992. Sexual performance of rams in serving capacity tests predicts success in pen breeding. J. Anim. Sci. 70, 2722-2725.

Plotka, E.D., Erb, R.E., 1969. Identification and excretion of estrogen in urine during the estrous cycle of the ewe. J. Anim. Sci. 29, 934-939.

Proud, C., Donovan, D., Kinsey, R., Cunningham, P.J., Zimmerman, D.R., 1976. Testicular growth in boars as influenced by selection for ovulation rate. J. Anim. Sci. 42, 1361 (abstract).

Purvis, I.W., 1985. Genetic relationships between male and female reproductive traits. Ph.D. Thesis. University of New England, Armidale, Australia.

Sanford, L.M., Palmer, W.M., Howland, B.E., 1977. Changes in the profiles of serum LH, FSH, and testosterone, and $\mathrm{n}$ mating performance and ejaculate volume in the ram during the ovine breeding season. J. Anim. Sci. 45, 1382-1391.

Snowder, G.D., Stellflug, J.N., Van Vleck, L.D., 2002. Heritability and repeatability of sexual performance of rams. J. Anim. Sci. 80, 1508-1511.

Terrill, C.E., 1937. Measurement of reproductive capacity as an aid in selection of rams of high fertility. Proc. Am. Soc. Anim. Prod., 311-312.

Tulley, D., Burfening, P.J., 1983. Libido and scrotal circumference of rams as affected by season of the year and altered photoperiod. Theriogenology 20, 435-448.

Wiggins, E.L., Terrill, C.E., Emik, L.O., 1953. Relationships between libido, semen characteristics and fertility in range rams. J. Anim. Sci. 12, 684-694. 